\title{
Post-dural puncture headache [Retraction]
}

A reader has highlighted the extensive similarities between:

1) Ahmed Ghaleb, Arjang Khorasani, and Devanand Mangar. Postdural Puncture Headache. Anesthesiol Res Pract. 2010; 2010: 102967.

And

2) Ghaleb A, Khorasani A, and Mangar D. Post-dural puncture headache. Int J Gen Med 2012:5 45-51.

Our investigations supported the readers claim of extensive and unreferenced text re-use and, as a result, the paper has been retracted.

\section{Publish your work in this journal}

The International Journal of General Medicine is an international, peer-reviewed open-access journal that focuses on general and internal medicine, pathogenesis, epidemiology, diagnosis, monitoring and treatment protocols. The journal is characterized by the rapid reporting of reviews, original research and clinical studies across all disease areas.
The manuscript management system is completely online and includes a very quick and fair peer-review system, which is all easy to use. Visit http://www.dovepress.com/testimonials.php to read real quotes from published authors. 